\title{
Recreational angling as a vector of freshwater invasions in Central Italy: perceptions and prevalence of illegal fish restocking
}

\author{
Jacopo Cerri ${ }^{1, *}$, Alessandro Ciappelli ${ }^{2}$, Andrea Lenuzza ${ }^{3}$, Marco Zaccaroni ${ }^{4}$ and Annamaria Nocita ${ }^{5}$ \\ ${ }^{1}$ Institute of Management, Scuola Superiore Sant'Anna, Pisa, Italy \\ 2 Dipartimento di Scienze delle Produzioni Agroalimentari e dell'Ambiente, Università di Firenze, Firenze, Italy \\ ${ }^{3}$ Regione Toscana, Firenze, Italy \\ ${ }^{4}$ Dipartimento di Biologia, Università di Firenze, Firenze, Italy \\ ${ }^{5}$ Museo di Storia Naturale, Università di Firenze, Firenze, Italy
}

\begin{abstract}
Italian freshwater ecosystems were strongly affected by biological invasions during the last few decades. Recreational angling contributed to this, through the widespread use of invasive alien species for fish restocking. To date, no research is available about the psychological and structural determinants of deliberate fish restocking in Italy. This work aims to fill this research gap, through structured questionnaires administered to a sample of recreational anglers $(n=276)$ in the Arno river basin (Central Italy). A predictive model for fish restocking, based on a quasi-binomial logistic regression, was fit and multi-model inference was drawn, to highlight the most significant predictors. Respondents, who expected that most anglers practiced restocking and who believed restocking could create closer fishing spots, were more prone to illegally restock fish. Our findings indicate that expectations about illegal fish restocking might exist among specialized segments of anglers. Targeted communication campaigns must be enforced as soon as possible to change them. Furthermore, fish restocking is supposed to reduce the travel costs for angling: future research about this is needed to model invasion hotspots.
\end{abstract}

Keywords: Recreational angling / restocking / aquatic invasions / survey / Italy

Résumé - La pêche à la ligne récréative en tant que vecteur d'invasion des eaux douces en Italie centrale: perception et prévalence de l'empoissonnement illégal. Les écosystèmes d'eau douce italiens ont été fortement touchés par les invasions biologiques au cours des dernières décennies. La pêche récréative y a contribué, grâce à l'utilisation généralisée d'espèces exotiques envahissantes pour le repeuplement en poissons. A ce jour, aucune recherche n'est disponible sur les déterminants psychologiques et structurels des empoissonnements délibérés en Italie. Ce travail vise à combler cette lacune de la recherche, par le biais de questionnaires structurés envoyés à un échantillon de pêcheurs récréatifs $(n=276)$ dans le bassin de l'Arno (Italie centrale). Un modèle prédictif des empoissonnements, basé sur une régression logistique quasibinomiale, a été ajusté et une inférence multi-modèle a été tirée, afin de mettre en évidence les prédicteurs les plus significatifs. Les répondants qui s'attendaient à ce que la plupart des pêcheurs à la ligne pratiquent le repeuplement et qui croyaient que le repeuplement pouvait créer des zones de pêche plus proches étaient plus enclins à repeupler illégalement. Nos résultats indiquent que des groupes de pêcheurs à la ligne pourraient avoir des attentes concernant le repeuplement illégal des poissons. Des campagnes de communication ciblées doivent être mises en œuvre dès que possible, afin de les modifier. De plus, la reconstitution des stocks de poissons est censée réduire les frais de déplacement pour la pêche à la ligne: des recherches futures à ce sujet sont nécessaires pour modéliser les points chauds d'invasion.

Mots-clés : Pêche récréative / repeuplement / invasions aquatiques / surveillance / Italie

\footnotetext{
*Corresponding author: j.cerri@santannapisa.it
} 


\section{Introduction}

Biological invasions are a major driver of change for freshwater ecosystems and they often interact with other important factors (MacDougall and Turkington, 2005; Rahel and Olden, 2008; Carpenter et al., 2011), reshaping biotic communities (Mollot et al., 2017) and affecting the provisioning of ecosystem services (Catford, 2017), ultimately resulting in substantial social costs (Perrings, 2002; Lovell et al., 2006).

In the last few decades, biological invasions increased both their frequency and their magnitude across a wide range of ecosystems worldwide (Turbelin et al., 2017), including freshwater (Gallardo et al., 2016). Traditionally, commercial boating is deemed to be the main pathway for aquatic invasions, as improper ballast water discharge can dramatically contribute to the accidental introduction of aquatic Invasive Alien Species (IAS) (Costello et al., 2007; Hulme, 2009) and commercial ships can transport propagules across long distances. However, other pathways for the spread of aquatic IAS have been identified as important, since the early 2000s (Zieritz et al., 2017). For example, recreational boating can be a major vector for IAS in freshwater ecosystems (Johnson et al., 2001; Clarke Murray et al., 2011; Anderson et al., 2014) and ornamental aquarium trade enhances the risk of aquatic IAS escaping from captivity, as well as their deliberate release in nature (Padilla and Williams, 2004; Duggan, 2010; Strecker et al., 2011). Recreational angling can be another important vector for invasive alien invertebrates and fish in freshwater, both in terms of accidental and deliberate introductions. Anglers can promote accidental introductions through a poor cleaning of angling equipment (Waterkeyn et al., 2010; Anderson et al., 2014), by improper bait disposal (Keller et al., 2007; Hendrix et al., 2008; DiStefano et al., 2009; Kilian et al., 2012) and by practicing restocking without enforcing biosecurity protocols (Gozlan et al., 2010). Furthermore, anglers can deliberately release invasive species in freshwater to increase their leisure experience: this can lead to the arrival of new fish species and it can seriously undermine eradication efforts (Cambray, 2003; Gozlan et al., 2010; Lorenzen, 2014).

To date, various human dimension studies have explored the role of recreational anglers in biological invasions, as human behaviour is a major source of uncertainty in fisheries and in the management of IAS (Fulton et al., 2011; Hunt et al., 2013). However, most of these works focused on at riskbehaviours which can lead to accidental introduction of aquatic IAS, like improper bait disposal or equipment cleaning (Gates et al., 2009; Seekamp et al., 2016), or on the potential effect of information provisioning and normative change as tools to prevent them (Azevedo-Santos et al., 2015; Howell et al., 2015; Pradhananga et al., 2015; Fujitani et al., 2016). On the other hand, fewer studies addressed drivers of deliberate fish introductions (Drake et al., 2015), especially for Mediterranean Europe (Banha et al., 2017a). This research gap must be addressed, as deliberate angling is responsible for the arrival of many invasive alien fish species in Mediterranean freshwater (Gherardi et al., 2008), including some major ecosystem engineers, like Silurus glanis (Carol et al., 2009; Copp et al., 2009), Cyprinus carpio (Vilizzi, 2012; Vilizzi et al., 2015), Micropterus salmoides (Garcia-Berthou et al., 2000) and Zander lucioperca (Lorenzoni et al., 2006; Kopp et al., 2009),

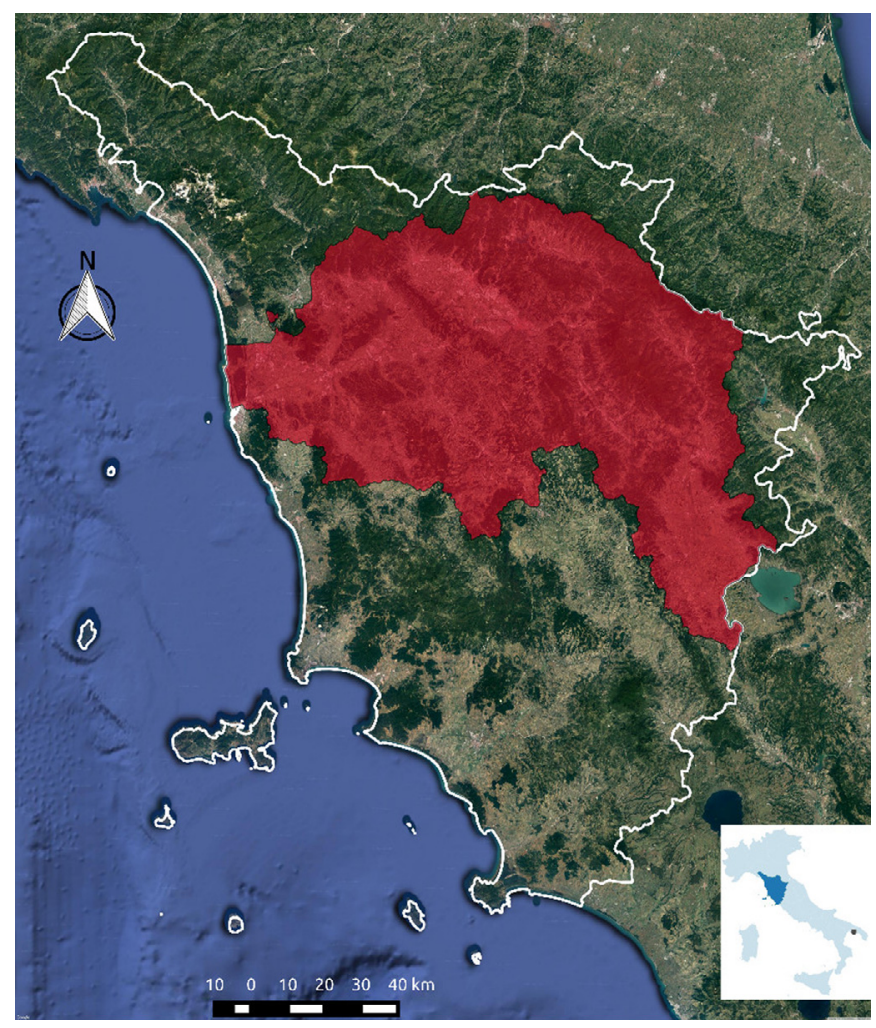

Fig. 1. Study area: the Arno basin in Tuscany (in red) and the Tuscany region in Italy (blue).

that can deeply reshape these ecosystems (Ribeiro and Leunda, 2012; Marr et al., 2013). This study aims to fill such of a gap in IAS management. Notably, we aimed to test the role of various potential drivers of fish restocking, including empirical expectations about angler behaviour, injunctive and descriptive norms, the perceived risk of sanctions and individual beliefs about the potential benefits and the ecological risks of fish restocking. Moreover, following what was suggested by Banha et al. (2017a), we tested whether regarding fish restocking as capable of providing closer fishing spots promoted such behaviour.

\section{Materials and methods}

The study area encompasses the proportion of the Arno river basin that lies in Tuscany, Central Italy (Fig. 1). The Arno river originates in Northern Apennines, its basin is $8228 \mathrm{~km}^{2}$ and it reaches the Tyrrhenian Sea after $214 \mathrm{~km}$. Its basin does not include any significant natural lake, but an unknown number of artificial lakes and ponds are present, as they originated from gravel pits that were subsequently abandoned and submerged. The Arno river has 13 main affluents and an average flow of about $110 \mathrm{~m}^{3} / \mathrm{s}$, which experiences considerable seasonal variations due to the Mediterranean climate of the basin and its morphology. For example, in winter, rainfalls range from over $2000 \mathrm{~mm}$ on the mountains in the NorthWestern portion of the basin, to $700 \mathrm{~mm}$ in the lowlands at its Easternmost border, and in the central portion of the Arno river, flows range from $3-4 \mathrm{~m}^{3} / \mathrm{s}$ in summer to $2000 \mathrm{~m}^{3} / \mathrm{s}$ in late autumn. Biological invasions strongly affected freshwater 
Table 1. Questions retained for data analysis: layout, format and summary.

\begin{tabular}{|c|c|c|}
\hline Question (layout) & Format & Summary \\
\hline Age (years) & Open-ended & Mean \pm sd $=40.67 \pm 14.18$ \\
\hline Gender & Dichotomous & Men $=96.85 \%$, Women $=3.15 \%$ \\
\hline Angling site & Multiple choice & $\begin{array}{l}\text { Fishing ponds }=59.89 \% \\
\text { Freshwater }=67 \% \% \\
\text { Sea }=44.16 \%\end{array}$ \\
\hline Angling technique & Multiple choice & $\begin{array}{l}\text { Coarse fishing }=62.9 \% \\
\text { Baitcasting }=60.9 \% \\
\text { Fly fishing }=15.7 \%\end{array}$ \\
\hline Empirical expectations & 10-Points rating scale & Mean $\pm \mathrm{sd}=3.20 \pm 2.84$ \\
\hline Beliefs about the level of discomfort & 7-Points rating scale & Mean $\pm \mathrm{sd}=3.87 \pm 2.43$ \\
\hline Perceived risk of sanctions & 7-Points rating scale & Mean $\pm \mathrm{sd}=3.72 \pm 2.29$ \\
\hline Awareness about the potential environmental consequences of fish restocking & 7-Points rating scale & Mean $\pm \mathrm{sd}=3.29 \pm 2.54$ \\
\hline Beliefs about the effectiveness of fish restocking & 7-Points rating scale & Mean $\pm \mathrm{sd}=6.21 \pm 1.41$ \\
\hline Perceived savings in travel costs & 7-Points rating scale & Mean $\pm \mathrm{sd}=3.26 \pm 2.25$ \\
\hline Descriptive norms about fish restocking & 7-Points rating scale & Mean \pm sd $=2.69 \pm 1.75$ \\
\hline Injunctive norms about fish restocking & 7-Points rating scale & Mean $\pm \mathrm{sd}=4.57 \pm 2.24$ \\
\hline Fish restocking & Dichotomous & Yes $=7.6 \%$ No $=92.4 \%$ \\
\hline
\end{tabular}

ecosystems in the basin, as about $70 \%$ of total aquatic animal species are invasive and some major ecosystem engineers are present (Gualtieri and Mecatti, 2005; Mari et al., 2009; Nocita, 2017). A complete list of native and invasive fish species for the Arno river is available in Nocita (2007), with the exclusion of the Albanian roach (Pachychilon pictum), which was recorded for the first time after 2007. In the study area a regional law regulates recreational angling (Regione Toscana, law n.7, 12/01/2005), fining rule violations with sanctions from 80 to $480 €$. Fish restocking is authorized for salmonids only, in those streams and water bodies that have been classified as suitable for trout fishing.

From November 2016 to January 2017, a total number of 276 anglers were involved in a survey about compliance with existing angling regulations and at-risk behaviours that could trigger aquatic invasions. Trained interviewers invited anglers to fill an anonymous paper-and-pencil questionnaire at fishing shops. As no public list of anglers exists in the study area, random sampling was impossible and purposive sampling was adopted. The questionnaire took approximately $10 \mathrm{~min}$ to fill and measured illegal fish restocking across freshwater bodies, altogether with respondents' demographics, information about their recreational angling experience and some antecedents of restocking. These antecedents were measured through single items, and they included empirical expectations about illegal restocking by anglers (Bicchieri and Xiao, 2009), the perceived risk of sanctions connected this practice (Elffers and Ruimschotel, 1997; Arias, 2015), the level of awareness about the potential environmental consequences of fish restocking (Selge et al., 2011; Drake et al., 2015; Banha et al., 2017), respondent's beliefs over the benefits of restocking over fish populations (Arlinghaus et al., 2014), beliefs about the potential capacity of fish restocking to provide closer fishing spots (Hunt et al., 2007; Beardmore et al., 2014; Banha et al., 2017), as well as injunctive and descriptive norms about fish restocking. The questionnaire is available in the Supplementary Materials (S1). Questions retained for data analysis and their proportion of missing answers are reported in Table 1 . The effect of the various drivers, demographics and recreational attributes of respondents, over self-reported fish restocking was assessed by fitting a logistic regression with a quasi-binomial distribution of the error to account for the overdispersion of observations caused by self-protecting strategies of some respondents, that were likely to deny any restocking behaviour, therefore increasing the proportion of negative answers in the response variable (Krumpal, 2013). Multimodel inference was adopted to estimate the relative weight of the various predictors over fish restocking by averaging a subset of candidate models. Model averaging was conducted over those candidate models whose quasi-AIC differed from the quasi-AIC of the best candidate model by a value greater than 5 . Furthermore, the area under the curve (AUC) and the pseudo- $R^{2}$ (Faraway, 2016) were calculated for the best candidate model to have an overall idea about its predictive power. Multicollinearity of predictors was assessed by graphi graphically inspection of the data and through the variance inflation factor (VIF). Statistical analysis was performed with the software R (R Core Team, 2017).

\section{Results}

Pilot questionnaires were easily completed, and they were retained for data analysis. A total of 197 questionnaires were selected for data analysis, discarding those completed by anglers who practiced sea fishing only. The percentage of unanswered questions was low (mean $\pm \mathrm{sd}=2.49 \pm 1.31 \%$ ). Our sample was almost entirely composed by male anglers $(96.85 \%)$ and we recorded an average age of $40.67 \pm 14.18$ years (mean $\pm \mathrm{sd}$ ). Our sample of respondents encompassed anglers who fished in private fishing ponds $(59.89 \%)$, freshwater $(67 \%)$ and sea $(44.16 \%)$. Coarse fishing was the most common type of fishing $(62.9 \%)$, followed by bait casting $(60.9 \%)$ and fly fishing $(15.7 \%)$. Respondents did not rate fish restocking as a particularly sensitive behaviour 


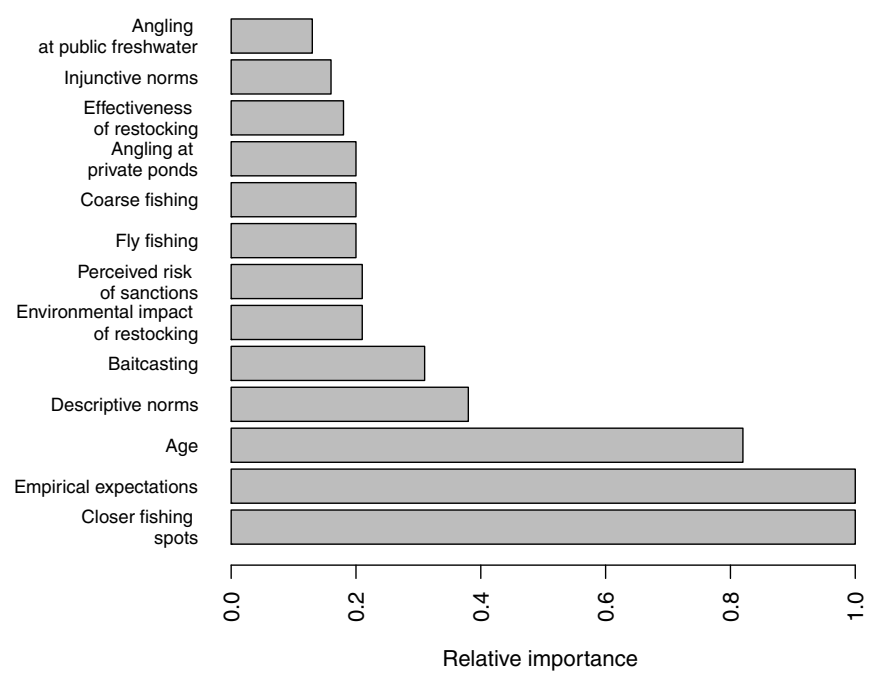

Fig. 2. Relative importance of the various predictors in the averaged models.

(mean $\pm \mathrm{sd}=3.87 \pm 2.43$ ) and $7.6 \%$ of them declared to restock fish across water bodies.

Data exploration did not suggest any pattern between the predictors and VIF values were all below 1.8; therefore, we found no evidence for multicollinearity. The best candidate model predicted $42 \%$ of variability in the data and its AUC was 0.90 . Model averaging was conducted on a very high number of candidate models $(\mathrm{n}=198)$, as the difference between their quasi-AIC and the quasi-AIC of the best candidate model was smaller than 5 . The coefficients and information criteria of the various candidate models are included in the Supplementary Materials (S2).

The relative importance of averaged predictors showed that age, empirical expectations about fish restocking and beliefs about the potential of restocking to create fishing spots nearby anglers' home were the most important predictors, followed by practicing baitcasting (Figs. 2 and 3 and Tab. 2). Moreover, descriptive norms about fish restocking and practicing baitcasting seemed to have some sort of effect over self-reported restocking behaviour. On the other hand, the perceived risk of sanction, individual beliefs about the environmental consequences of restocking, practicing fly fishing or coarse fishing, the dominant site of angling, beliefs about the effectiveness of fish restocking as a practice to restore fish populations and injunctive norms about this practice, did not have any strong effect over the response variable.

\section{Discussion}

To the best of our knowledge, our research provides various novelties to the science of aquatic invasions. Despite various studies addressed the ecological (Ribeiro and Leunda, 2012; Marr et al., 2013) and genetic (Marzano et al., 2003; Madeira et al., 2005; Gandolfi et al., 2017) consequences of indiscriminate fish introductions, and some researchers monitored the angling community to map aquatic invasions in Mediterranean freshwaters (Gago et al., 2016; Banha et al., 2017 b), very few studies actually explored the drivers of illegal
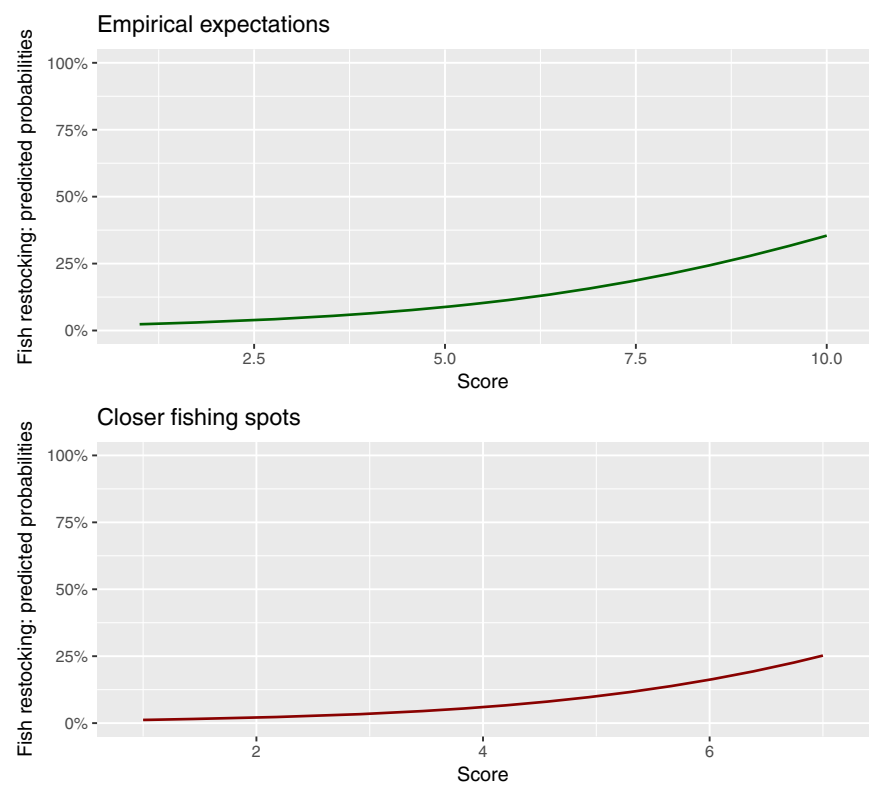

Fig. 3. Effect of empirical expectations and perceived advantages of fish restocking to obtain closer fishing spots: predicted probabilities over the response variable in the best candidate model.

fish restocking by means of questionnaires. To the best of our knowledge, the only study doing so was Banha et al. (2017a), where web-based questionnaires were administered at two samples of recreational anglers in Portugal and Spain, highlighting some major drivers of illegal fish introductions in Iberian freshwater and underlining some country-specific differences. Indirectly, Rees et al. (2017) also explored the socio-economic attributes of specialized European catfish anglers in the UK, and their perception of catfish impacts, discussing some potential implications for deliberate catfish restocking in the UK. Therefore, our study is one of the few of this kind, and arguably the only one for Italy, contributing to extend the application of human dimension research into the field of invasion biology. Our findings denounce a concerning situation in the study area: anglers are far from being adequately informed about the environmental consequences and the potential sanctions connected with unauthorized fish restocking. In fact, respondents generally agreed with the idea that restocking operations do not have any consequence on freshwater ecosystems. This point indicates a lack of information about the potential adverse consequences of indiscriminate restocking, which is a mandatory step to raise stakeholder awareness towards biological invasions (GarcíaLlorente et al., 2008). This finding agrees with what has been noticed by Rees et al. (2017) about European catfish anglers in the UK, who had low levels of awareness of the environmental risks connected with catfish restocking and of the environmental impact of the species. However, they contrast with the findings of Banha et al. (2017a), who noticed that Spanish and Portuguese anglers were generally aware of the negative ecological impact of introduced species, and that they only ignored the effect of aquatic invasions in terms of reduced provisioning of ecosystem services.

Furthermore, respondents generally disagreed with the idea that police and fisheries officers have a good control over 
Table 2. Output of the averaged models.

\begin{tabular}{|c|c|c|c|c|c|}
\hline Term & Estimate & $\mathrm{SE}$ & Adj. SE & $Z$-value & $p$-value \\
\hline \multicolumn{6}{|c|}{ Model-averaged coefficients: full average } \\
\hline Intercept & -5.42300 & 2.52615 & 2.54011 & 2.135 & $0.0328(* *)$ \\
\hline Age & -0.04167 & 0.04100 & 0.04120 & 1.012 & 0.3118 \\
\hline Perceived savings in travel costs & 0.60802 & 0.26809 & 0.26977 & 2.254 & $0.0242(* *)$ \\
\hline Empirical expectations & 0.37978 & 0.16342 & 0.16444 & 2.310 & $0.0209(* *)$ \\
\hline Baitcasting & -0.24509 & 0.62553 & 0.62817 & 0.390 & 0.6964 \\
\hline Descriptive norms & 0.08364 & 0.21828 & 0.21932 & 0.381 & 0.7029 \\
\hline Environmental impact of restocking & 0.02141 & 0.10614 & 0.10671 & 0.201 & 0.8410 \\
\hline Fly fishing & -0.15006 & 0.78524 & 0.78948 & 0.190 & 0.8493 \\
\hline Coarse fishing & 0.09611 & 0.50547 & 0.50815 & 0.189 & 0.8500 \\
\hline Injunctive norms & -0.01503 & 0.10299 & 0.10357 & 0.145 & 0.8846 \\
\hline Perceived risk of sanctions & -0.02129 & 0.11191 & 0.11251 & 0.189 & 0.8499 \\
\hline Effectiveness of restocking & -0.03093 & 0.20538 & 0.20654 & 0.150 & 0.8809 \\
\hline Angling at ponds & 0.09640 & 0.52039 & 0.52319 & 0.184 & 0.8538 \\
\hline Angling at freshwater bodies & 0.03289 & 0.39233 & 0.39465 & 0.083 & 0.9336 \\
\hline \multicolumn{6}{|c|}{ Model-averaged coefficients: conditional average } \\
\hline Intercept & -5.42300 & 2.52615 & 2.54011 & 2.135 & $0.0328(* *)$ \\
\hline Age & -0.05056 & 0.03987 & 0.04012 & 1.260 & 0.2076 \\
\hline Perceived savings in travel costs & 0.60802 & 0.26809 & 0.26977 & 2.254 & $0.0242(* *)$ \\
\hline Empirical expectations & 0.37978 & 0.16342 & 0.16444 & 2.310 & $0.0209(* *)$ \\
\hline Baitcasting & -0.77920 & 0.90983 & 0.91560 & 0.851 & 0.3948 \\
\hline Descriptive norms & 0.22080 & 0.30903 & 0.31096 & 0.710 & 0.4777 \\
\hline Environmental impact of restocking & 0.10216 & 0.21334 & 0.21470 & 0.476 & 0.6342 \\
\hline Fly fishing & -0.74249 & 1.61591 & 1.62609 & 0.457 & 0.6479 \\
\hline Coarse fishing & 0.48909 & 1.05262 & 1.05917 & 0.462 & 0.6442 \\
\hline Injunctive norms & -0.09323 & 0.24186 & 0.24340 & 0.383 & 0.7017 \\
\hline Perceived risk of sanctions & -0.10304 & 0.22842 & 0.22984 & 0.448 & 0.6539 \\
\hline Effectiveness of restocking & -0.17605 & 0.46316 & 0.46608 & 0.378 & 0.7056 \\
\hline Angling at ponds & 0.49164 & 1.08943 & 1.09625 & 0.448 & 0.6538 \\
\hline Angling at freshwater bodies & 0.25100 & 1.05823 & 1.06479 & 0.236 & 0.8136 \\
\hline
\end{tabular}

Significance code: $*=0.1, * *=0.05, * * *=0.01$.

angling, and the variable did not have any strong effect in the models. Considered that perceived risk is a crucial factor to prevent noncompliance about natural resources (Elffers and Ruimschotel, 1997; Arias, 2015), this indicates that stricter and more capillary control schemes are needed to enforce existing regulations about angling. Finally, anglers in our sample did not believe in their peers' disapproval towards illegal restocking, deeming that an angler in their area would only feel mildly uncomfortable if he was forced to admit illegal restocking operations to other people. This point seems to be confirmed by the lack of any significant effect of injunctive norms over the response variable, despite social norms traditionally are powerful deterrents for noncompliance in using natural resources (Manfredo et al., 2009; St John et al., 2011; Heberlein, 2012).

Such of an absence of information, police controls and social norms are reflected in the role played by empirical expectations and descriptive norms. Empirical expectations drive rational decision-making, when no information is available about others' behaviour (Bicchieri and Xiao, 2009): as anglers do not possess any information about the consequences of fish restocking, nor about any formal and informal sanction about it, their behaviour is guided by their expectations about other anglers' behaviour. In our case, the more respondents believed that other anglers practiced restocking, the higher the chance they engaged in fish restocking as well. The effect of empirical expectations is confirmed by a moderate effect of descriptive norms, which had a moderate influence over the response variable, in the averaged models. To the best of our knowledge, no information campaign has ever been conducted against illegal restocking, nor about invasive alien fish, in the study area. Provided that these initiatives must be adequately tailored to the various types of anglers (Eiswerth et al., 2011; Gozlan et al., 2013), we believe that providing information could lay the foundations for counteracting illegal fish stocking and the introduction of IAS by anglers. Despite information per se is often insufficient to stimulate environmental change (Heberlein, 2012), it is crucial, together with stricter police control and structural changes, to foster good stewardship practices by anglers and to promote large-scale increases in the level of compliance and pro-environmental norms (Bruskotter and Fulton, 2008; Cooke et al., 2013). Disseminating information among anglers will also promote the early detection of new aquatic IAS (Hargrove et al., 2015) and could help managers in developing partnerships with the angling community to map introduction hotspots and to identify non-compliant anglers. 
Our research also confirms the importance of another driver of fish introductions: the willingness to obtain closer fishing spots. In our model, the belief that fish restocking would enable anglers to create fishing spots in proximity of their home was one of the strongest predictors of illegal fish stocking. These results are not entirely surprising, as travel costs are one of the main factors explaining the quality of leisure experiences in outdoor recreation (Smith, 1989; Fletcher et al., 1990) and various human dimension studies identified distances as variables that can seriously affect the quality of angling experience (Arlinghaus and Mehner, 2004; Hunt, 2005; Beardmore et al., 2014). Moreover, Banha et al. (2017a) obtained similar findings from a survey with recreational anglers in the Iberian peninsula, showing that fish were introduced for the convenience of having closer fishing spots providing anglers with a good angling experience. We believe that this aspect could have various implications for predicting and managing the deliberate spread of invasive fish species, as landscape affects angler's distribution and recruitment (Post et al., 2008; Hunt et al., 2017). Choice experiments or factorial survey could be very useful to characterize those fishing spots which are at risk of invasive fish release, not only in terms of their distance from anglers, but also on the basis of their attributes, like the density of recreational anglers or their natural surroundings (Rees et al., 2017). Moreover, these techniques could also account for angler-specific attributes over the evaluation of a specific angling site, like the preference for invasive or native species (Banha et al., 2017a) or individual awareness about aquatic invasions and the impact of invasive fish (Banha et al., 2017a; Rees et al., 2017), through multi-level modelling. We certainly encourage future studies adopting these quasi-experimental approaches that could contribute to increase our understanding of illegal fish restocking. In fact, our model, despite being acceptable in terms of predictive power, could be certainly improved, as shown by the value of the pseudo- $R^{2}$.

The age of respondents had a relatively neutral effect over the probability of deliberately restocking fish; however, it was retained in most candidate models, despite often not significant, and it had quite a high relative importance. Age is a conventional driver of non-compliant behaviour, which is traditionally more common until early adulthood (Steffensmeier et al., 1989), and we encourage future studies disentangling its role in illegal fish restocking. For example, by exploring how fish restocking is age-dependent, future policy interventions aimed at discouraging this practice could be tailored for the various age segments of the angling community, who might have different reasons for noncompliance, as well as different ways to access and integrate information in their decision-making.

From our findings, it must be noticed that, despite practicing baitcasting had a moderate effect over averaged models, the various forms of angling did not have a strong effect over probability to engage in fish restocking. This could sound strange, because some major aquatic invaders in the study area are targeted by specialized anglers through baitcasting (e.g. largemouth bass, M. salmoides) or coarse fishing (e.g. European catfish, S. glanis). However, our questionnaire did not collect any information about the frequency of the various angling techniques, nor about their application to the various fish species. This probably led to some confounding effect in the model: for example, most anglers who practice baitcasting could target native salmonids, rather than invasive species. In turn, this confounding effect could result in baitcasting having a relatively low predictive power, and even a negative marginal effect, over restocking behaviour. Future studies should better characterize anglers in terms of their angling techniques and the application of the various techniques to the various fish species.

Moreover, future studies should also understand which species are restocked across water bodies. This research gap is particularly urgent, because anglers do not only restock invasive alien fish, but also native ones, and this practice could lead to disease transmission and the loss of genetic diversity among populations of native fish species.

\section{References}

Anderson LG, White PC, Stebbing PD, Stentiford GD, Dunn AM. 2014. Biosecurity and vector behaviour: evaluating the potential threat posed by anglers and canoeists as pathways for the spread of invasive non-native species and pathogens. PLoS One 9: e 92788.

Arias A. 2015. Understanding and managing compliance in the nature conservation context. J Environ Manage 153: 134-143.

Arlinghaus R, Mehner T. 2004. A management-orientated comparative analysis of urban and rural anglers living in a metropolis (Berlin, Germany). Environ Manage 33: 331-344.

Arlinghaus R, Beardmore B, Riepe C, Meyerhoff J, Pagel T. 2014. Species-specific preferences of German recreational anglers for freshwater fishing experiences, with emphasis on the intrinsic utilities of fish stocking and wild fishes. J Fish Biol 85: 1843-1867.

Azevedo-Santos VM, Pelicice FM, Lima-Junior DP, BarrosoMagalhaes AL, Orsi ML, Simoes Vitule JR, Agostinho AA. 2015. How to avoid fish introductions in Brazil: education and information as alternatives. Nat Conservacao 13: 123-132.

Banha F, Diniz A, Anastácio PM. 2017. The role of anglers' perceptions and habits in biological invasions: perspectives from the Iberian Peninsula. Aquat Conserv 27: 51-64.

Banha F, Veríssimo A, Ribeiro F, Anastácio PM. 2017. Forensic reconstruction of Ictalurus punctatus invasion routes using on-line fishermen records. Knowl Manag Aquat Ecosyst 418: 56.

Beardmore B, Hunt LM, Haider W, Dorow M, Arlinghaus R. 2014. Effectively managing angler satisfaction in recreational fisheries requires understanding the fish species and the anglers. Can J Fish Aquat Sci 72: 500-513.

Bicchieri C, Xiao E. 2009. Do the right thing: but only if others do so. J Behav Decis Making 22: 191-208.

Bruskotter JT, Fulton DC. 2008. Minnesota anglers' fisheries-related value orientations and their stewardship of fish resources.Hum Dimens Wildl 13: 207-221.

Cambray JA. 2003. Impact on indigenous species biodiversity caused by the globalisation of alien recreational freshwater fisheries. Hydrobiologia 500: 217-230.

Carol J, Benejam L, Benito J, García-Berthou E. 2009. Growth and diet of European catfish (Silurus glanis) in early and late invasion stages. Fund Appl Limnol 174: 317-328.

Carpenter SR, Stanley EH, Vander Zanden MJ. 2011. State of the world's freshwater ecosystems: physical, chemical, and biological changes. Ann Rev Environ Resour 36: 75-99.

Catford JA. 2017. Hydrological impacts of biological invasions. In Vilà M, Hulme P, eds.Impact of Biological Invasions on Ecosystem Services. New York: Springer, pp. 63-80.

Clarke Murray C, Pakhomov EA, Therriault TW. 2011. Recreational boating: a large unregulated vector transporting marine invasive species. Divers Distrib 17: 1161-1172. 
Cooke SJ, Suski CD, Arlinghaus R, Danylchuk AJ 2013. Voluntary institutions and behaviours as alternatives to formal regulations in recreational fisheries management. Fish Fish 14: 439-457.

Copp GH, Robert Britton J, Cucherousset J, García-Berthou E, Kirk R, Peeler E, Stakènas S. 2009. Voracious invader or benign feline? A review of the environmental biology of European catfish Silurus glanis in its native and introduced ranges. Fish Fish 10: 252-282.

Costello C, Drake JM, Lodge DM. 2007. Evaluating an invasive species policy: ballast water exchange in the Great Lakes. Ecol Appl 17: 655-662.

DiStefano RJ, Litvan ME, Horner PT. 2009. The bait industry as a potential vector for alien crayfish introductions: problem recognition by fisheries agencies and a Missouri evaluation. Fisheries 34: 586-597.

Drake DAR, Mercader R, Dobson T, Mandrak NE. 2015. Can we predict risky human behaviour involving invasive species? A case study of the release of fishes to the wild. Biol Invasions 17: 309-326.

Duggan IC. 2010. The freshwater aquarium trade as a vector for incidental invertebrate fauna. Biol Invasions 12: 3757-3770.

Eiswerth ME, Yen ST, van Kooten GC. 2011. Factors determining awareness and knowledge of aquatic invasive species. Ecol Econ 70: $1672-1679$.

Elffers H, Ruimschotel D. 1997. The Table of Eleven (T11) as a new content oriented paradigm for evaluation research. In: Proceedings of the 2nd European Evaluation Society Conference.

Faraway JJ. 2016. Extending the Linear Model with R: Generalized Linear, Mixed Effects and Nonparametric Regression Models. Boca Raton: CRC Press, p. 394.

Fletcher JJ, Adamowicz WL, Graham-Tomasi T. 1990. The travel cost model of recreation demand: theoretical and empirical issues. Leisure Sci 12: 119-147.

Fujitani ML, McFall A, Randler C, Arlinghaus R. 2016. Efficacy of lecture-based environmental education for biodiversity conservation: a robust controlled field experiment with recreational anglers engaged in self-organized fish stocking. J Appl Ecol 53: 25-33.

Fulton EA, Smith AD, Smith DC, van Putten IE. 2011. Human behaviour: the key source of uncertainty in fisheries management. Fish Fish 12: 2-17.

Gago J, Anastácio P, Gkenas C, Banha F, Ribeiro F. 2016. Spatial distribution patterns of the non-native European catfish, Silurus glanis, from multiple online sources - a case study for the River Tagus (Iberian Peninsula). Fish Manag Ecol 23: 503-509.

Gallardo B, Clavero M, Sánchez MI, Vilà M. 2016. Global ecological impacts of invasive species in aquatic ecosystems. Glob Change Biol 22: 151-163.

Gandolfi A, Ferrari C, Crestanello B, Girardi M, Lucentini L, Meraner A. 2017. Population genetics of pike, genus Esox (Actinopterygii, Esocidae), in Northern Italy: evidence for mosaic distribution of native, exotic and introgressed populations. Hydrobiologia 794: 73-92.

García-Llorente M, Martín-López B, González JA, Alcorlo P, Montes C. 2008. Social perceptions of the impacts and benefits of invasive alien species: implications for management. Biol Conserv 141: 2969-2983

Gates K, Guy C, Zale A, Horton T. 2009. Angler awareness of aquatic nuisance species and potential transport mechanisms. Fish Manag Ecol 16: 448-456.

Gherardi F, Bertolino S, Bodon M, Casellato S, Cianfanelli S, Ferraguti M, Lori E, Mura G, Nocita A, Riccardi N, Rossetti G, Rota E, Scalera R, Zerunian S, Tricarico E. 2008. Animal xenodiversity in Italian inland waters: distribution, modes of arrival, and pathways. Biol Invasions 10: 435-454.
Gozlan R, Britton J, Cowx I, Copp G. 2010. Current knowledge on non-native freshwater fish introductions. $J$ Fish Biol 76: 751-786.

Gozlan RE, Burnard D, Andreou D, Britton JR. 2013. Understanding the threats posed by non-native species: public vs. conservation managers. PloS One 8: e 53200.

Gualtieri M, Mecatti M. 2005. Distribution and age of European catfish (Silurus glanis L.) in the Arno river, Florence province . Biological Invasion in Inland Water.

Hargrove JS, Weyl OL, Allen MS, Deacon NR. 2015. Using tournament angler data to rapidly assess the invasion status of alien sport fishes (Micropterus spp.) in Southern Africa. PloS One 10: e 0130056

Heberlein TA. 2012. Navigating Environmental Attitudes. Oxford: Oxford University Press, p. 240.

Hendrix PF, Callaham Jr, MA, Drake JM, Huang CY, James SW, Snyder BA, Zhang W. 2008. Pandora's b***ox contained bait: the global problem of introduced earthworms. Annu Rev Ecol Evol 39: 593-613.

Howell AP, Shaw BR, Alvarez G. 2015. Bait shop owners as opinion leaders: a test of the theory of planned behavior to predict proenvironmental outreach behaviors and intentions. Environ Behav 47: $1107-1126$.

Hulme PE. 2009. Trade, transport and trouble: managing invasive species pathways in an era of globalization. $J$ Appl Ecol 46: 10-18.

Hunt L, Sutton S, Arlinghaus R. 2013. Illustrating the critical role of human dimensions research for understanding and managing recreational fisheries within a social-ecological system framework. Fish Manag Ecol 20: 111-124.

Hunt LM. 2005. Recreational fishing site choice models: insights and future opportunities. Hum Dim Wildl 10: 153-172.

Hunt LM, Bannister AE, Drake DAR, Fera SA, Johnson TB. 2017. Do fish drive recreational fishing license sales? N Am J Fish Manage 37: $122-132$.

Hunt LM, Boots BN, Boxall PC. 2007. Predicting fishing participation and site choice while accounting for spatial substitution, trip timing, and trip context. N Am J Fish Manage 27: 832-847.

Johnson LE, Ricciardi A, Carlton JT. 2001. Overland dispersal of aquatic invasive species: a risk assessment of transient recreational boating. Ecol Appl 11: 1789-1799.

Keller RP, Cox AN, Van Loon C, Lodge DM, Herborg L-M., Rothlisberger J. 2007. From bait shops to the forest floor: earthworm use and disposal by anglers. Am Midl Nat 158: 321-328.

Kilian JV, Klauda RJ, Widman S, Kashiwagi M, Bourquin R, Weglein S, Schuster J. 2012. An assessment of a bait industry and angler behavior as a vector of invasive species. Biol Invasions 14: 1469-1481.

Kopp D, Cucherousset J, Syväranta J, Martino A, Céréghino R, Santoul F. 2009. Trophic ecology of the pikeperch (Sander lucioperca) in its introduced areas: a stable isotope approach in southwestern France. $C$ R Biol 332: 741-746.

Krumpal I. 2013. Determinants of social desirability bias in sensitive surveys: a literature review. Qual Quant 47: 2025-2047.

Lorenzen K. 2014. Understanding and managing enhancements: why fisheries scientists should care. J Fish Biol 85: 1807-1829.

Lorenzoni M, Mearelli M, Ghetti L. 2006. Native and exotic fish species in the Tiber River watershed (Umbria-Italy) and their relationship to the longitudinal gradient. B Fr Peche Piscic 382: $19-44$.

Lovell SJ, Stone SF, Fernandez L. 2006. The economic impacts of aquatic invasive species: a review of the literature. Agric Resour Econ Rev 35: 195.

MacDougall AS, Turkington R. 2005. Are invasive species the drivers or passengers of change in degraded ecosystems? Ecology 86: $42-55$. 
Madeira MJ, Gómez-Moliner BJ, Barbe AM. 2005. Genetic introgression on freshwater fish populations caused by restocking programmes. Biol Invasions 7: 117-125.

Manfredo MJ, Teel TL, Henry KL. 2009. Linking society and environment: a multilevel model of shifting wildlife value orientations in the western United States. Soc Sci Quart 90: 407-427

Mari L, Casagrandi R, Pisani MT, Pucci E, Gatto M. 2009. When will the zebra mussel reach Florence? A model for the spread of Dreissena polymorpha in the Arno water system (Italy). Ecohydrology 2: 428-439.

Marr SM, Olden JD, Leprieur F, Arismendi I, Caleta I, Morgan DL, Nocita A, Sanda R, Tarkan S, García-Berthou E. 2013. A global assessment of freshwater fish introductions in mediterraneanclimate regions. Hydrobiologia 719: 317-329.

Marzano FN, Corradi N, Papa R, Tagliavini J, Gandolfi G. 2003. Molecular evidence for introgression and loss of genetic variability in Salmo (trutta) macrostigma as a result of massive restocking of Apennine populations (Northern and Central Italy). Environ Biol Fish 68: 349-356.

Mollot G, Pantel J, Romanuk T. 2017. The effects of invasive species on the decline in species richness: a global meta-analysis. Adv Ecol Res 56: 61-83.

Nocita A, Tricarico E, Bertolino S. 2017. Fine-scale analysis of heavily invaded Italian freshwater fish assemblages. Integr Zool 12: $500-511$.

Nocita A. 2007. La fauna ittica del bacino dell'Arno. Biologia Ambientale 21: 97-105.

Padilla DK, Williams SL. 2004. Beyond ballast water: aquarium and ornamental trades as sources of invasive species in aquatic ecosystems. Front Ecol Environ 2: 131-138.

Perrings C. 2002. Biological invasions in aquatic systems: the economic problem. Bull Mar Sci 70: 541-552.

Post J, Persson L, Parkinson Ev, Kooten Tv. 2008. Angler numerical response across landscapes and the collapse of freshwater fisheries. Ecol Appl 18: 1038-1049.

Pradhananga A, Davenport MA, Seekamp E, Bundy D. 2015. Preventing the spread of aquatic invasive species: boater concerns, habits, and future behaviors. Hum Dim Wildl 20: 381-393.

Rahel FJ, Olden JD. 2008. Assessing the effects of climate change on aquatic invasive species. Conserv Biol 22: 521-533.
Ribeiro F, Leunda P. 2012. Non-native fish impacts on Mediterranean freshwater ecosystems: current knowledge and research needs. Fish Manag Ecol 19: 142-156.

Seekamp E, McCreary A, Mayer J, Zack S, Charlebois P, Pasternak L. 2016. Exploring the efficacy of an aquatic invasive species prevention campaign among water recreationists. Biol Invasions 18: $1745-1758$.

Selge S, Fischer A, van der Wal R. 2011. Public and professional views on invasive non-native species - a qualitative social scientific investigation. Biol Conserv 144: 3089-3097.

Smith VK. 1989. Taking stock of progress with travel cost recreation demand methods: theory and implementation. Mar Resour Econ 6: 279-310.

Steffensmeier DJ, Allan EA, Harer MD, Streifel C. 1989. Age and the distribution of crime. Am J Sociol 94: 803-831.

St John FA, Edwards-Jones G, Jones JP. 2011. Conservation and human behaviour: lessons from social psychology. Wildlife Res 37: 658-667.

Strecker AL, Campbell PM, Olden JD. 2011. The aquarium trade as an invasion pathway in the Pacific Northwest. Fisheries 36: 74-85.

Turbelin AJ, Malamud BD, Francis RA. 2017. Mapping the global state of invasive alien species: patterns of invasion and policy responses. Global Ecol Biogeogr 26: 78-92.

Vilizzi L. 2012. The common carp, Cyprinus carpio, in the Mediterranean region: origin, distribution, economic benefits, impacts and management. Fish Manag Ecol 19: 93-110.

Vilizzi L, Tarkan A, Copp G. 2015. Experimental evidence from causal criteria analysis for the effects of common carp Cyprinus carpio on freshwater ecosystems: a global perspective. Rev Fish Sci Aquac 23: 253-290.

Waterkeyn A, Vanschoenwinkel B, Elsen S, Anton-Pardo M, Grillas P, Brendonck L. 2010. Unintentional dispersal of aquatic invertebrates via footwear and motor vehicles in a Mediterranean wetland area. Aquat Conserv 20: 580-587.

Zieritz A, Gallardo B, Baker SJ, Britton R., van Valkenburg JLCH, Verreycken H, Aldridge DC. 2017. Changes in pathways and vectors of biological invasions in Northwest Europe. Biol Invasions 19: $269-282$.

Cite this article as: Cerri J, Ciappelli A, Lenuzza A, Zaccaroni M, Nocita A. 2018. Recreational angling as a vector of freshwater invasions in Central Italy: perceptions and prevalence of illegal fish restocking. Knowl. Manag. Aquat. Ecosyst., 419, 38. 